\title{
PERSPEKTIF M.NATSIR TENTANG SUBYEK DAKWAH
}

\author{
Fethan Werdaty \\ UIN RADEN FATTAH PALEMBANG \\ werdaty.fethan@gmail.com
}

\begin{abstract}
ABSTRAK
Prophet as an actor first preaching in the life of Islam, with persistent and knows no despair, he delivered the message of Islam until his death. In connection with it as ukhairu ummah" then any Muslim either individually or in groups should inherit the position as the subject of preaching is not the object of propaganda let alone act as someone who does not do anything. Muslim communities must be at the core and is responsible for calling on people to take an active role of truth and prevent those things from falsehood, so that the goal can be achieved with the Islamic da'wah well and smoothly in accordance with what is expected.

To carry out and deliver da'wah to its target objects, there are many methods or methods carried out by ulama, Da'i and da'wah practitioners, all of which rely on efforts to convey religious messages or Islamic values. In this regard, when the message of preaching will be delivered to the object, the thing that must be considered is the creation of a process of acceptance and understanding of da'wah messages in an atmosphere that is good and peaceful, does not lead to contra, divisive or even confusing understanding which results in no achieved the expected missionary purpose.

On the one hand, the essence of da'wah in the socio-cultural system is to organize and provide direction for change. Changing the structure of society and culture from tyranny towards justice, ignorance towards progress / intelligence, poverty towards prosperity, all backwardness towards progress in order to improve the degree of humans and society towards the peak of humanity (tawa).

The obligation to carry out Islamic da'wah, is certainly closely related to the commands of Allah SWT. In the A1-Qur'an, among the arguments that show the obligation of da'wah are listed in the which means the following: "And let there be among you a group of people who call upon virtue, send to those who speak and prevent from the poor, they are the lucky ones.
\end{abstract}

Key Words: Da'wah Study, M Natsir 


\section{A. PENDAHULUAN}

Al-Qur'an surat Ali Imron ayat 110 menyatakan bahwa kedudukan dan peranan umat Islam adalah sebagai "Kuntum Khaira Ummnah", sebagai umat yang paling baik, umat yang harus menjadi contoh bagi umat yang lainnya. Posisi yang mulia tersebut diperoleh karena sikap hidup seseorang muslim didasarkan pada keimanan kepada Allah SWT. Serta diiringi oleh sikap aktif melaksanakan ihsan (berbuat baik), amar ma'ruf nahi munkar, sebuah usaha menyebarluaskan kebenaran, mengajak seseorang pada kebajikan dan mencegah dariperbuatan kemunkaran.

Dakwah merupakan satu bagian yang pasti ada dalam kehidupan umat beragama. Dalam ajaran agama Islam ia merupakan suatu kewajiban yang dibebankan oleh agama kepada pemeluknya. Oleh karena itu fungsi dari misi umat Islam di tengah-tengah kehidupan masyarakat sangat besar dan berat, sebab mereka harus berdiri di baris terdepan sebagai pejuangpejuang penegak kebenaran, kewajiban yang berat ini dibebankan kepada generasi pengikut Muhammad Saw yang beriman secara terus-menerus. Tidak satupun yang terlepas dari kewajiban berat ini. Itulah kewajiban Iqamatu Hujjatillahi (menegakkan hukum Allah) kepada manusia, dan kewajiban untuk menyelamatkan manusia dari azab akhirat dan kebinasaan di dunia. Kewajiban ini ditunaikan dengan menyampaikan risalah dan melaksanakan sesuai manhajyang dibawa oleh Rasulullah SAW. ${ }^{1}$

Jika kita melihat perjalanan hidup Rasulullah SAW sebagai pelaku dakwah pertama dalam kehidupan Islam,dengan gigih dan tidak mengenal putus asa, beliaumenyampaikan risalah Islam hingga akhir hayatnya.Sehubungan dengan itu sebagai "Khairu Ummnat" makasetiap muslim baik secara perorangan maupunberkelompok haruslah mewarisi posisi sebagai subyekdakwah bukan menjadi obyek dakwah apalagi bertindaksebagai sosok yang tidak berbuat apa-apa. Masyarakatmuslim harus menjadi inti dan bertanggung jawab untukberperan aktif menyeru manusia kepada yang haq danmencegah dari hal-hal bathil, sehingga tujuan dakwahIslam dapat tercapai dengan baik dan lancar sesuaidengan apa yang diharapkan.

Islam adalah agama risalah untuk manusia keseluruhan, Allah SWT berfirman yang artinya: "Dan tidaklah kami mengutus Engkau melainkan untuk membawa berita gembira dan peringatan kepada seluruh umat manusia". (QS. Saba': 28). ${ }^{2}$

Umat Islam adalah pendukung amanah, untuk meneruskan Risalah dengan dakwah sesuai dengan kemampuan masing-masing:"Sampaikanlah daripadaku walau pun satu ayat" (HR.Bukhari). Dengan demikian maka jelas

${ }^{1}$ Jum'ah Amin Abdul Aziz, Fiqh Dakwah, Intermedia, (Jakarta: Cet. 1, 2000) h. 29
2 Departemen Agama RI, Al-Qur'an dan Terjemahnya, (Jakarta: Ruhama, 1999) h. 125 
bahwa kewajiban berdakwah tidak hanya terbeban pada para ulama atau orang-orang yang menguasai ilmu agama Islam saja, akan tetapi setiap pribadi muslim mempunyai kewajiban untuk melaksanakan tugas suci tersebut.

Melaksanakan perintah dakwah di dalam Islam dinyatakan sebagali satu pekerjaan yang bernilai Jihad Fi Sabilillah, pengertian jihad bisa berbentuk menyampaikan informasi, memberikan pengertian, memberikan pendidikan dan bimbingan bahkan bisa dalam bentuk memerangi kaum kafir.

Untuk melaksanakan dan menyampaikan dakwahpada obyek sasarannya, maka banyak cara atau metode yang dilakukan oleh para ulama, Da'i maupun praktisi-praktisi dakwah, yang kesemuanya bertumpu pada upaya menyampaikan pesan-pesan agama atau nilai-nilai ajaran Islam. Sehubungan itu semua, ketika pesan dakwah akan disampaikan pada obyeknya, maka hal yang harus diperhatikan adalah terciptanya proses penerimaan dan pemahaman pesan dakwah dalam suasana yang baikdan damai, tidak menimbulkan sikap kontra, memecahbelah atau bahkan membingungkan dan mengaburkan pemahaman yang justru berakibat pada tidak tercapai tujuan dakwah yang diharapkan.

Di satu pihak bahwa esensi dakwah dalam systemsosio-kultural adalah mengadakan dan memberikan arah perubahan. Mengubah struktur masyarakat dan budaya dari kezhaliman kearah keadilan, kebodohan kearah kemajuan/kecerdasan, kemiskinan kearah kemakmuran, keterbelakangan kearah kemajuan yang semuanya dalam rangka meningkatkan derajat manusia dan masyarakat kearah puncak kemanusiaan (takwa). ${ }^{3}$

\section{B. KEWAJIBAN DAKWAH}

Kewajiban untuk melaksanakan dakwah Islam, tentunya erat terkait dengan perintah Allah SWT. Di dalam A1-Qur'an, diantara dalil yang menunjukkan kewajiban dakwah adalah terteradalam Surat A1-Imron ayat 104 yang artinya sebagai berikut: "Dan hendaklah ada di antara kamu segolongan umat yang menyeru kepada kebajikan, menyuruh kepadayang ma'ruf dan mencegah dari yang munkar, merekalah orang-orang yang beruntung". (QS. Al-Imron: 104). 4

Ayat tersebut di atas menunjukkan kewajiban berdakwah atas semua manusia, baik dalam bentuk Fardhu Kifayah maupu Fardhu 'Ain dalam pengertian lain hendaklah semua kaum muslimin menjadi umat yang

${ }^{3}$ Amrullah Ahmad, Dakwah dan Perubahan Sosial, Editor, (Jakarta: PLP2M, 1998), h.

${ }^{4}$ Departemen Agama RI, Op. Cit, h. 185 
mengajak kepada kebaikan dan melarang kemunkaran. Surat Ali- Imron ayat 104 tersebut mempunyai relevansi terhadap Firman Allah SWT dalam surat Ali-Imron ayat 110:5

Artinya: "kamu adalah umat yang terbaik yang dilaihirkan untuk manusia, menyuruh kepada yang ma'ruf dan mencegah dari yang munkar, dan beriman kepada Allah". (QS. Al-Imron: 11O).

Berdasarkan pada makna kedua ayat yang dikemukakan di atas, maka kewajiban untuk melaksanakan dakwah diwajibkan kepada umat muslim baik secara perorangan maupun berjama'ah/kelompok, dengan satu prinsip yang berorientasi pada Izzul Islam Wal Muslimin.

\section{Da'i Dalam Pandangan M. Natsir}

Bila seorang pembawa dakwah sudah mengayunkan langkah, maka bermacam corak sikap dan tabiat manusia yang akan dijumpai. Seorang da'I mungkin saja akan dihadapkan kepada orang yang berilmu tapi sulit untuk menerima kebenaran, atau orang bodoh akan sulit untuk memahami nilai-nilai kebenaran dan lain sebagainya. Oleh karena itu,obyek dakwah yang beraneka ragam ditemukan harus dihadapi dengan sebuah analisa Homogenitas tingkat kemampuan kecerdasan, sikap dan tabiat masingmasing.

Sebuah rujukan yang harus diperhatikan oleh seorang petugas dakwah/ da'i adalah firman Allah dalam surat Al-Qur'an sebagai berikut:

Artinya: "Serulah (manusia) kepada jalan Tuhanmu dengan hikmah dan pelajaran yang baik dan bantahlah mereka dengan cara yang baik. Sesungguhnya Tuhanmu Dialah yang lebih mengetahui tentang siapa yang tersesat dari jalan-Nya dan Dialah yang lebih mengetahui orang-orang yang mendapat petunjuk. (QS. AnNahl: 125).

Syech Muhammad Abduh, menyimpulkan dari ayat A1-Qur'an di atas, bahwa dalam garis besarnya umat yang dihadapi seseorang pembawa dakwah dapat dibagi atas tiga golongan:

1. Ada golongan cendikiawan yang cinta kebenaran,dan dapat berfikir secara kritis, cepat dapat menangkap arti persoalan. Mereka ini harus dipanggil dengan hikmah yakni dengan alasan-alasan, dengan dalildalil dan hujjah yang dapat diterima oleh kekuatan akal mereka.

2. Ada golongan awam, orang kebanyakan yang belum dapat menangkap pengertian-pengertian yang tinggi-tinggi, mereka ini dipanggil dengan "Mau'idzatil Hasanah" dengan anjuran dan didikan yang baik-baik, dengan ajaran yang mudah dipahami.

3. Ada golongan yang tingkat kecerdasan diantara kedua golongan tersebut, belum dapat dicapai dengan hikmah, akan tetapi tidak sesuai pula bila dilayani seperti golongan awam, mereka suka 
membahas sesuatu, tetapi hanya dalam batas tertentu, tidak sanggup sampai mendalam benar. Mereka ini dipanggil dengan "Mujadalah Billati Hiya Ahsan", yakni dengan bertukar pikiran, guna untuk menyampaikan dakwah pada sasaran yang telah disebutkan di atas, maka harus diperhatikan beberapa hal sebagai berikut:

a. Seorang pembawa dakwah/da'i harus mampu menentukan cara yang tepat dan efektif, seorang da'i harus menguasai isi dakwah yang hendak disampaikan, harus dapat menilai apa corak orang atau golongan yang dihadapi, memahami situasi dan kondisi di mana ia menyampaikan dakwah dan inilah yang disebut hikmah.

Dalam tafsir Al-Manar Syekh Muhammad Abduh mengatakan bahwa:

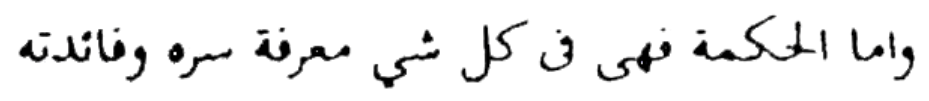

"Adapun hikmah adalah memahamkan rahasia dan faedah tiap-tiap sesuatu"

Dengan memahamkan rahasia dan faedah sesuatu (segala sesuatu, dalam arti segala unsur-unsur yang berhimpun dalam melakukan dakwah, unsur isi dakwah, unsur manusia yang dihadapi, unsur keadaan, ruang dan waktu, unsur bentuk dan cara berdakwah yang sesuai), dalam paduan yang seimbang antara pengetahuan itu dengan rasa periksa, sehingga merupakan daya penggerak untuk sesuatu langkah yang tepat, dengan itulah seorang muballigh dapat menentukan dan menjalankan kaifiat dakwah yang efektif. ${ }^{6}$

Sebagai i'tibar dalam perjalanan dakwah yang dilakukan Rasul Muhammad SAW, beliau dianggap sebagai penyeleweng yang mengajak ummat manusia pada kesesatan, oleh Abu Lahab dianggap sebagai orang yang akan membawa malapetaka, akan tetapi pernyataan-pernyataan yang bersifat negatif tersebut dihadapi oleh Rasul dengan sikap damai dan tetap berupaya secara sungguh-sungguh untuk mengajak umat manusia pada kebenaran, yang pada akhirnya disambut dengan pernyataan Ali bin Abi Thalib:

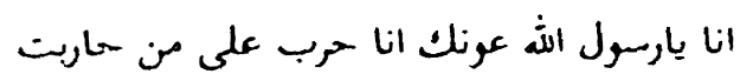

"Aku ya Rasulullah: aku membelamu, aku adalah musuh bagi yang memusuhimu". 
Peristiwa tersebut di atas penting untuk menjadi perhatian seorang muballigh atau da'i, sehingga tidak terjebak pada istilah "ayam gadis baru bertelur, rintang berkotat sepanjang hari", tenaga terbuang-buang, sedangkan hasilnya tidak seberapa, malah seringkali negatif.

b. Seorang da'i harus mampu mengadakan kontak pemikiran dan mencari titik pertemuan sebagai tempat bertolak untuk maju secara sistematis Akan sulit bagi seorang mubaligh/da'i memulai tugasnya apabila ia tidak mendapat kontak sama sekali. Bertambah sulit lagi apabila lantaran tidak mengenal lapangan operasinya, dia masuk tanpa perhitungan sama sekali, lalu belum apa-apa sudah menimbulkan pertentangan (antipasti), yang sebenarnya bisa dihindarkan dan sama sekali tidak perlu. Ajaran-ajaran Islam sendiri cukup mempunyai daya tarik. Bagi seorang Mubaligh soalnya ialah: memilih cara yang tepat untuk menyampaikan dengan daya panggilan yang menarik pula. ${ }^{7}$

c. Seorang da'i harus mampu mengendalikan diri, memelihara keseimbangan dan ketenangan jiwa, dan menghindarkan pemborosan tenaga dengan sia-sia. Kadang-kadang seorang muballigh/da'I dihadapkan pada sasaran dakwah yang memang sulit, sehingga usaha dakwah yang dilakukan macet, bila ini yang ditemukan, Allah SWT memberikan tuntunan dalam al-Qur'an sebagai berikut:

Artinya: "Mereka itu adalah : orang-orang yang Allah mengetahui apa yang di dalam hati mereka. karena itu berpalinglah kamu dari mereka, dan berilah mereka pelajaran, dan Katakanlah kepada mereka perkataan yang berbekas pada jiwa mereka. (QS. An-Nisa: 63) 


\section{Simpulan}

Dari uraian-uraian maka dikemukakan simpulannya : bahwa dakwah merupakan kewajiban yang harus dilakukan oleh pribadi muslim baik secara pribadi maupun secara berkelompok (para da'i/muballigh, lembaga agama, dll). Dalam melaksanakan tugas seorang da'i harus mampu mengetahui tingkat kemampuan sasaran dakwah, kondisi, materi dakwah (hikmah).

Seorang da'i mampu mengadakan kontak pemikiran, mampu menganalisa, menghitung dan memprediksi sasaran dakwah. Syarat mutlak bagi seorang da'i adalah harus mengetahui nilai-nilai ajaran Islam dan harus menjadi contoh yang baik/uswatun hasanah, baik perkataan maupun perbuatannya, Seorang Da'i harus. mempunyai akhlakul karimah, sebagaimana akhlak Rasulullah. Bahwa keberhasilan dakwah sangat bergantung pada kesungguhan dan kemampuan para da'i untuk melaksanakannya secara sistematis dan professional. 


\section{DAFTAR PUSTAKA}

Asmuni Sukir, Dasar-Dasar Strategi Dakwah, Surabaya, 1970.

Amrullah Ahmad, Dakwah Islam Dan Perubahan, Editor, Sosial, LPP2M

Abdullah Karim Zaidan, Dasar-Dasar Ilmu Dakwah, Media Dakwah, 1979.

M. Natsir, Fiqhul Dakwah II, Yayasan Dakwah Islamiyah, Surabaya, 1970.

M. Quraish shihab, Membumikan Al-Qur`an, MIZAN, 1994.

Jum`ah Amin Abdul Aziz, Figh Dakwah, Intermedia, 2000.

Toha Yahya Umar, Ilmu Dakwah, Wicaksana, Semarang, 1992.

Toto Tasmara, Komunikasi Dakwah, Jakarta, Gayamedia Pratama, 2001.

Thomas W. Arnold, Sejarah Dakwah Islam, Wijaya, Jakarta, 1985.

Syaikh Abdurrahman Abdul Khaliq, Metode Dan Strategi Dakwah Islam, Pustaka Al-Kautsar, 1996. 